\title{
Evaluation of eutrophication in the Ria Formosa coastal lagoon, Portugal
}

\author{
A. Newton ${ }^{\mathrm{a}}$, J.D. Icely ${ }^{\mathrm{b}, *}$, M. Falcao ${ }^{\mathrm{c}}$, A. Nobre ${ }^{\mathrm{d}}$, J.P. Nunes ${ }^{\mathrm{d}}$, J.G. Ferreira ${ }^{\mathrm{d}}$, \\ C. Vale \\ a IMAR, FCT, Gambelas Campus, University Algarve, Faro 8000-117, Portugal \\ ${ }^{\mathrm{b}}$ Sagremarisco, Apt 21, Vila do Bispo 8650-999, Portugal \\ ' IPIMAR Av. Brasilia, Lisboa 1400, Portugal \\ ${ }^{\mathrm{d}}$ IMAR-CEM, DCEA, FCT, Qta. Torre, Monte Caparica 2829-516, Portugal
}

Received 27 February 2002; accepted 30 June 2003

\begin{abstract}
The Ria Formosa is a shallow mesotidal lagoon on the south coast of Portugal, with natural biogeochemical cycles essentially regulated by tidal exchanges at the seawater boundaries and at the sediment interface. Existing data on nutrients in the water column and the sediment, together with chlorophyll $a$ and oxygen saturation in the water column, are compared using different models for assessing eutrophication. The European Environmental Agency criteria are based on the comparison of nutrient concentrations which indicate that the situation in the Ria Formosa is "poor" to "bad". In contrast, the United States Estuarine Eutrophication Assessment is based on symptoms, including high chlorophyll $a$ and low oxygen saturation, which indicate that the Ria Formosa is near pristine.

Despite these contradictions, a preliminary assessment by Driving forces, Pressures, State, Impact, Reponses (DPSIR) of eutrophication demonstrate the potential for episodic eutrophic conditions from treated and untreated domestic effluent as well as from non-point source agricultural run off. Sediments are also an important source of nutrients in the lagoon, but their contribution to potential eutrophic conditions is unknown.
\end{abstract}

(C) 2003 Elsevier Ltd. All rights reserved.

Keywords: Eutrophication; Coastal lagoon; Sediments; Nutrients; Chlorophyll $a$; Oxygen saturation; EU-WFD; US-NEEA; Portugal

\section{Introduction}

The quality of coastal waters in many regions of the world has deteriorated in recent years as human population and activities have increased along coastal regions. Human activities have more than doubled the amount of nitrogen in the

\footnotetext{
*Corresponding author. Fax: + 351-282-639004.

E-mail addresses: anewton@ualg.pt (A. Newton), alicely@mail.telepac.pt (J.D. Icely).
}

environment globally from 1960 to 1990 (NRC, 2000), with the use of synthetic fertilisers accounting for more than half of that growth. The nitrogen in these fertilisers seeps into ground water, rivers, and streams, gradually making its way into coastal waters. Other sources of nitrogen include animal wastes, wastewater treatment plants, and the combustion of fossil fuels. These fuels release nitrogen compounds into the atmosphere that fall in acid rain, adding significant amounts of nitrogen to some coastal waters (Paerl 
et al., 2002). Inputs of phosphorous from agricultural sources and detergents have also increased since the 1950s (Vollenweider, 1976). However, long term studies by the European Environmental Agency (EEA) have shown some improvements in the last decade of the 20th century (EEA, 1999a).

Elevated inputs of nutrients can produce eutrophication that has been defined by the EEA as "an increase in the rate of supply of organic matter to an ecosystem, which most commonly is related to nutrient enrichment enhancing the primary production in the system" (EEA, 2001). Eutrophication was first recognised as a problem in freshwaters and continues to be a problem in European freshwater systems (Cardoso et al., 2001), despite the implementation of measures to protect and to restore freshwater ecosystems in many countries.

Eutrophication of coastal waters is a more recently recognised phenomenon, the scientific understanding of which is still in progress (Cloern, 2001). A survey of the USA estuaries found that $70 \%$ were affected to some degree by eutrophication (Bricker et al., 1999; NRC, 2000). Problems are particularly severe along the mid-Atlantic coast, Chesapeake Bay and the Gulf of Mexico, where a "dead zone" forms along the Louisiana and Texas coasts each spring (Turner and Rabalais, 1994). Eutrophication in European coastal waters was assessed by the EEA (1999a, b, 2001). It was concluded that although there were improvements in the quality of coastal waters, these were still not adequate to achieve the targets hoped for by the EEA.

Coastal lagoons are particularly vulnerable to eutrophication. They are regions of restricted exchange (RRE) with the adjacent ocean and, thus, may accumulate nutrients supplied by the surrounding watershed (Caumette et al., 1996; Taylor et al., 1999). The EEA call such zones physically sensitive areas (PSA).

The conceptual model of eutrophication is still evolving and there are many models, indicators and indices currently in use i.e.: the USA "symptom" based model (Bricker et al., 1999); the new trophic index (TRIX) proposed by Vollenweider et al. (1998); the estuarine quality index EQUATION (Ferreira, 2000); Nixon's (1995) assessment based on phytoplankton primary production.
In addition to assessments of actual conditions of eutrophication, the Joint Research Centre of the European Union (Druon et al., 2002) is developing a risk index (EUTRISK) as an indicator of European coastal areas sensitive to eutrophication. EUTRISK is based on observations of high and frequent phytoplankton biomass in the top layer determined as chlorophyll by remote sensing. This is combined with another indicator based on physical climatology and called the physically sensitive areas (PSA) index, that will help to separate regions with high physical resistance to eutrophication and oxygen depletion (good flushing and deep waters) from regions with low physical resistance (poor flushing and shallow waters).

The EEA (1999a, 2001) suggests that there is potential for eutrophication within the estuaries and lagoons of the Iberian coastal areas, including the Ria Formosa along the eastern part of the south coast of Portugal (Fig. 1). This lagoon of 10,000 ha includes 5000 ha of salt marsh and mud flats, 2000 ha of sand banks and 1000 ha of saltpans and aquaculture ponds. The Ria Formosa and some of its hinterland has been included in a 78,000 ha national park, in recognition of its environmental value. Also, the lagoon also has been recognised as an important wetland at both a European and an International level by its acceptance as a Natura 2000 and a Ramsar site. The Ria Formosa is a valuable regional resource to the Algarve for tourism, fisheries, aquaculture and salt extraction-all industries that rely on good water quality.

However, there are a number of pressures on the Ria Formosa including urbanization, intensive agriculture, aquaculture, and coastal engineering such as artificial inlets. There is evidence of some undesirable changes occurring in the lagoon system, such as a declining bivalve harvest: in 1989 around 7000 tons of clams were harvested from the sand flats of the lagoon, supplying $90 \%$ of the Portuguese market, but this declined to 2000 tons by 1990 (Dinis, 1992). These losses have been attributed to the deterioration in water quality, although a direct link has still to be conclusively established.

There have been studies on metals and organic biomarkers of pollution of this lagoon (Bebianno, 1995; Mudge and Bebianno, 1997, 1998; Mudge 


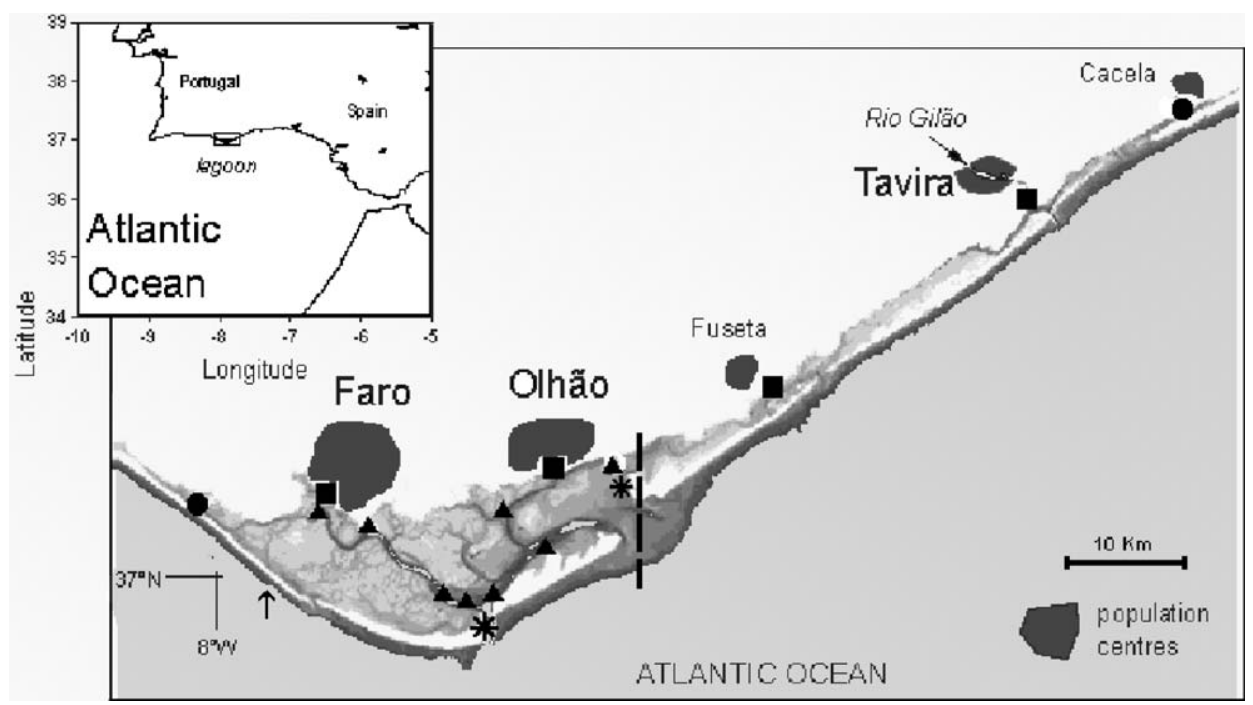

Fig. 1. Inset: geographical location of the Ria Formosa lagoon. Map of the lagoon showing the 16 sampling stations for the water column represented by a range of symbols: $\boldsymbol{O}$, landward boundary conditions; $*$, seaward boundary conditions; $\boldsymbol{\Delta}$, intermediate lagoon conditions; $\mathbf{\square}$, exposure to domestic sewage and/or freshwater. Stations to the east (right) of the vertical broken line are from the eastern lagoon; stations to the west (left) of the vertical broken line are from the western lagoon. Sediments were sampled from mud and sandflats between Olhão and Fuseta. Arrow shows the artificial inlet that was opened during the INDIA project in 1997.

et al., 1998, 1999), as well as a survey of the degree of faecal pollution in the lagoon (Dionisio et al., 2000). However, there has been relatively little analysis of existing data to provide a model for comparison with the current water quality in the lagoon, particularly, with regard to eutrophication. New interpretations of existing data are useful tools in reconstruction scenarios and for the development of management strategies (Jackson, 2001).

Nutrients in the water column and the sediments, chlorophyll $a$ and oxygen saturation are important parameters used in the models for assessing eutrophication (see references above). Data on these parameters are presented for the Ria Formosa to provide a preliminary evaluation of the potential for Eutrophication in the Ria Formosa using Driving forces, Pressures, State, Impact, Responses (DPSIR). This evaluation will contribute to a proposal for water quality management that is currently being developed within the OAERRE (Oceanographic Applications to Eutrophication in Regions of Restricted ExchangeEloise cluster, Framework 5) project in accordance with the aims of the Water Framework Directive of the European Union (EU-WFD).

\section{Methods}

\subsection{Survey of nutrients in the water column}

Sixteen sampling stations were selected in the Ria Formosa, both to give adequate spatial coverage, and to represent the variety of conditions in the lagoon: stations at the seawater inlets represented the seaward boundary conditions $(*$ in Fig. 1); stations at the ends of the channels represented the landward boundary conditions ( in Fig. 1); stations located along the channels from the landward to the seaward boundary represented intermediate conditions in the lagoon $(\boldsymbol{\Delta}$ in Fig. 1); stations located close to towns and a station close to the mouth of the Gilão river represented, respectively, areas subjected to domestic sewage and freshwater inputs ( $\square$ in Fig. 1).

Samples and in situ data were collected from these stations each month from June 1987 to May 1988 inclusive. Sampling dates coincided with neap tides when tidal flushing was minimal and possible deterioration in water quality most likely. The effects of tidal flushing were assessed by sampling at both high water and low water. 
The samples were analysed directly in the laboratory, or frozen (at $-20^{\circ} \mathrm{C}$ ) for later analysis. Small sample volumes $\left(5 \mathrm{~cm}^{3}\right)$ were analysed in triplicate for ammonium-nitrogen, nitrite-nitrogen, nitrate-nitrogen, orthophosphate-phosphorus and silicate-silicon, utilising methods described in Grasshoff et al. (1983).

\subsection{Modelling of nutrient data measured in the water column}

Interpretation of nutrient data in the water column in terms of geographical information systems (GIS) is based on the modelling scheme used for the Tagus Estuary by Simas et al. (2001). Nutrient ratios were collated from the nutrient survey of the water column for the "summer" months, May-September, and for the "winter" months, October-April, to prepare nutrient maps by the Geographical Information System (GIS) for both low and high water in the lagoon. Two masks were constructed from the bathymetric data for the lagoon based on a mean high tide of $3.03 \mathrm{~m}$ and a mean low tide of $0.97 \mathrm{~m}$ (Andrade, 1990). The method of interpolation assumed that each station, or input point, had a local influence that diminished with distance away from the station (Inverse Distance Weighted in Isaaks and Srivastava, 1989). The stations used for the nutrient maps are shown in Fig. 1 and can be compared with the hydrographic maps on salinity and temperature in Newton and Mudge (in press).

\subsection{Analysis of nutrients in sediment cores}

Intertidal lagoon flats at Marim (between Olhão and Fuseta in Fig. 1) were sampled in June 2000 and February 2001. 6 cores of $10 \mathrm{~cm}$ length and $5 \mathrm{~cm}$ diameter were taken randomly from the lagoon flats that had been exposed at low tide for three hours. A further 30 cores were taken after immersion by the flood tide. Cores were sliced immediately, in loco, into thin layers: 0-2, 2-4, 4-6 and $6-8 \mathrm{~cm}$. Each layer was placed immediately in polyethylene vials to minimise changes induced by exposure to the atmosphere. Pore water was extracted immediately in the laboratory by centrifuging specific sediment layers pooled from three sediment cores. Overlying water was collected from the same sites as the sediment cores. All water samples were filtered through $0.45 \mu \mathrm{m}$ Nucleopore membranes and kept at $-20^{\circ} \mathrm{C}$ for later analysis of ammonium-nitrogen, nitrite-nitrogen, nitrate-nitrogen, orthophosphate-phosphorus and silicate-silicon using the methods of Technicon Industrial Systems modified from Grasshoff et al. (1983).

\subsection{Chlorophyll a assessment}

220 estimates of chlorophyll $a$ in the Ria Formosa were collated from the relational data base BarcaWin 2000. Samples were taken twice a month during spring tide (low-tide and high tide) and neap tide (low-tide and high tide), between 1985 and 1986 (Falcão, 1997) from the main channels in the lagoon (see $\boldsymbol{\Delta}$ in Fig. 1) and several sites along the eastern lagoon (Fig. 1). Chlorophyll $a$ was estimated by the standard fluorometric method (Yentsch and Menzel, 1963).

\subsection{Oxygen assessment}

912 measurements for oxygen saturation in the Ria Formosa were summarised from the relational BarcaWin 2000 data base. Samples were collected over several sampling campaigns between 1985 and 1989 (Newton, 1995; Falcão, 1997) from a wide range of sites throughout the lagoon, including all the sites shown in Fig. 1. Oxygen was estimated by the standard Winkler technique with a Dosimat "Metrohm Herisau" (Grasshoff, 1976).

\section{Results}

All data presented in this paper are available to the public through the relational database BarcaWin 2000 and the data base of the European Union OAERRE project.

\subsection{Survey of the water column in the Ria Formosa}

The data for this survey of nutrients in the water column of the Ria Formosa has been described in more detail in Newton (1995) and Newton and 
Mudge (submitted). The analysis of the data shows marked differences between the mean concentrations of nutrients from 13 sample sites (Fig. 1) in the western lagoon and the 3 sites in the eastern lagoon.

A comparison of the seasonal changes in the mean concentrations of dissolved available inorganic nitrogen (DAIN), phosphate, and silicate are presented in Fig. 2. The mean concentration of DAIN fluctuated around $20 \mu \mathrm{mol} \mathrm{dm}^{-3}$ with greater concentrations in the eastern lagoon compared to the western (Fig. 2A). This difference was greatest during the winter months, with concentrations in the eastern lagoon increasing up to $150 \mu \mathrm{mol} \mathrm{dm}^{-3}$. The mean concentrations of phosphate are generally greater than $0.6 \mu \mathrm{mol} \mathrm{dm}^{-3}$ and, except in February, are always higher in the eastern lagoon compared to the western lagoon (Fig. 2B). There are peaks up to $1.4 \mu \mathrm{mol} \mathrm{dm}^{-3}$ during late spring and early summer months, but decreasing to below $0.8 \mu \mathrm{mol} \mathrm{dm}^{-3}$ during the late summer and early autumn. The concentrations of phosphate increase during the late autumn and the early winter, particularly, in the eastern lagoon where it increases up to $1.2 \mu \mathrm{mol} \mathrm{dm}{ }^{-3}$ in November. The mean concentrations of silicate are generally low for most of the year (Fig. 2C), with an increase during the winter months to $80 \mu \mathrm{mol} \mathrm{dm}^{-3}$ in the western lagoon and a much greater $600 \mu \mathrm{mol} \mathrm{dm}^{-3}$ in the eastern lagoon. There is a noticeable reduction in all the nutrient concentrations throughout the lagoon at specific periods during the spring months. Some of the nutrient changes may be related to inflows of freshwater from the Gilão and Almargem that are located in the eastern lagoon. During the sampling period, the influx of freshwater is notably high during October and December (INAG, 2002).

A comparison of the DAIN:P (Fig. 3A) ratio between the western and eastern lagoon throughout the sampling period shows relatively low ratios during the spring and then fluctuates between 15 and 60 for the rest of the year. However, in the eastern lagoon, there is a substantial increase of up to 140 during the winter. In the case of the DAIN:Si, the ratio (Fig. 3B) in both the western and eastern lagoon is low for most of the year. However, during late spring and the summer months, there are fluctuations in the ratio between

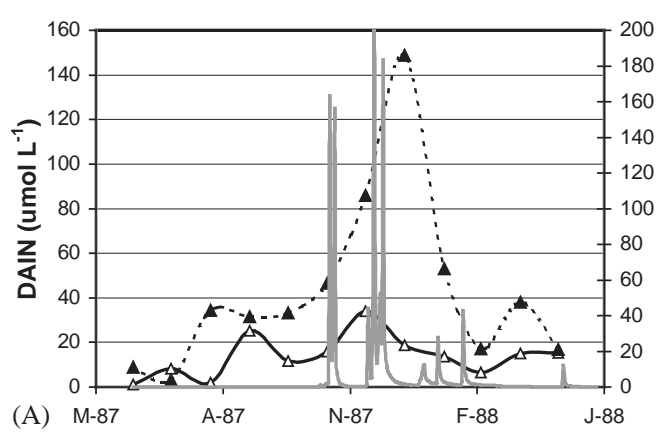

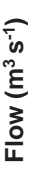
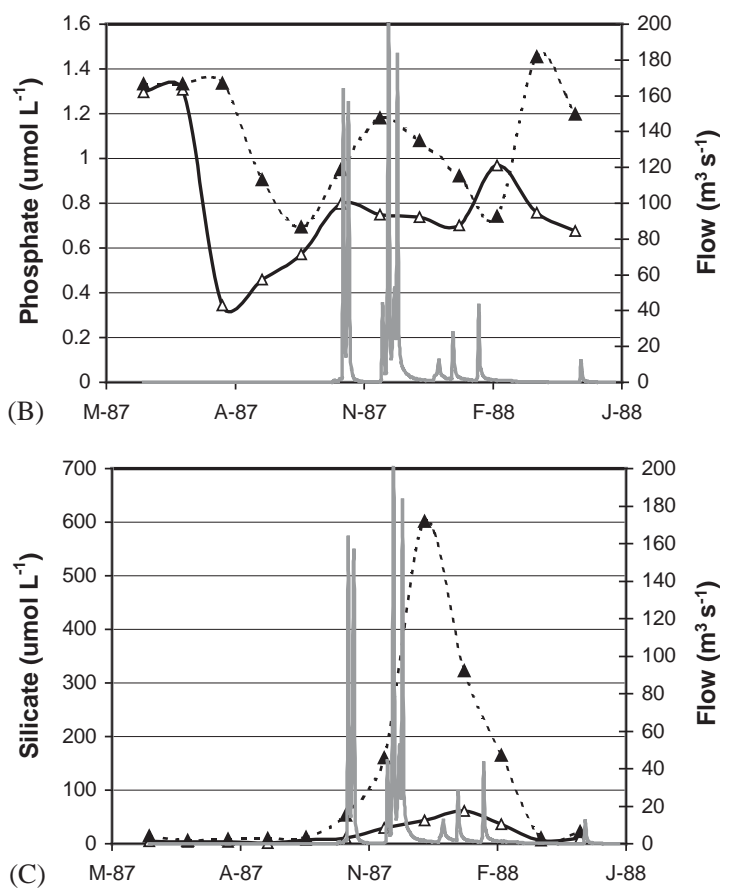

Fig. 2. Seasonal changes in the mean concentrations of nutrients collected monthly from 13 stations in the western lagoon ( $\triangle$, solid curve) and from 3 stations in the eastern lagoon ( $\boldsymbol{\Lambda}$, broken curve). (A) Dissolved available inorganic nitrogen (DAIN); (B) phosphate; (C) silicate. The nutrient concentrations are related to the velocity of river flow into the lagoon (grey curve) recorded by the Portuguese Water Institute (INAG, 2002).

1 and 5, with a sharp increase during August of up to 19 in the western lagoon.

The ratios DAIN:P and DAIN:Si are analysed further by the use of GIS maps (Figs. 4 and 5) based on the data collected at the stations shown in Fig. 1. The maps display the summer conditions in $\mathrm{A}$ and the winter conditions in $\mathrm{B}$ at both low water 

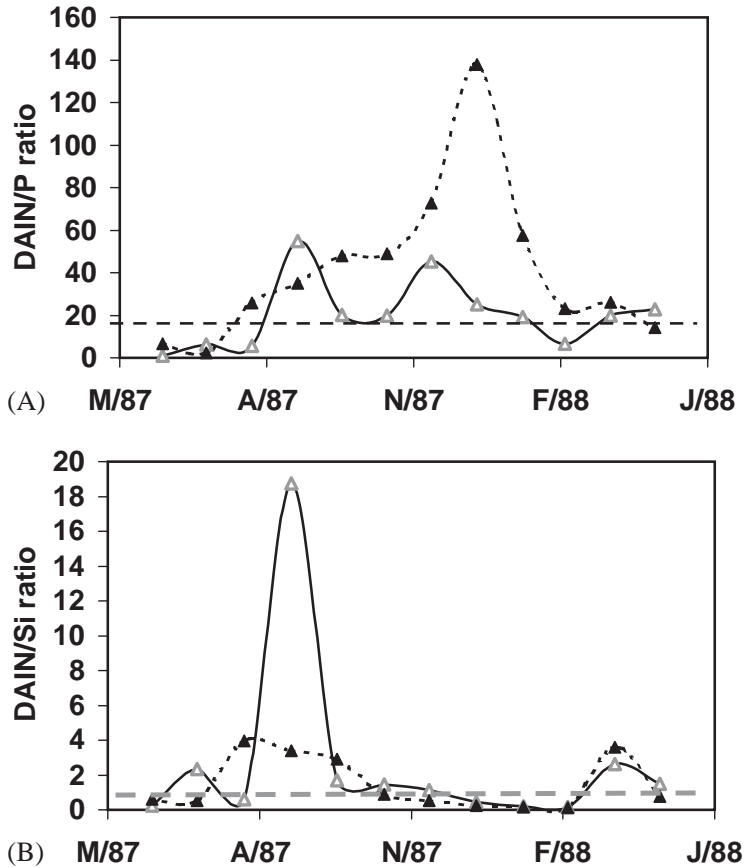

Fig. 3. Seasonal changes in the ratios of nutrients collected from stations in the western lagoon ( $\triangle$, solid curve) and from those in the eastern lagoon ( $\boldsymbol{\Delta}$, broken curve). (A) DAIN:phosphate; (B) DAIN: Silicate. The broken grey lines represent Redfield ratios considered typical for coastal waters.

in I and high water in II. White and light shades are areas where the ratios are close to a "balanced" condition (EEA, 1999a), whilst darker shades show ratios that have deviated from the "balanced" condition. The DAIN:P ratio (Fig. 4) under summer conditions is close to the normal Redfield ratio of 16 in the middle of the western lagoon, but it is greater than 16 for most of the inner lagoon. However, near the urban centers of Faro and Olhão and adjacent to the seawater inlets, the ratio is less than 16. This is also the case in the far east of the lagoon. The deviations from normal are more pronounced during winter conditions. The outer regions close to the seawater inlets of the western lagoon show below average ratios, and the inner region of the western lagoon and the entire eastern lagoon show above average ratios. The GIS maps of the DAIN:Si ratios (Fig. 5) show a marked difference between the summer and the winter situations. Most of the lagoon has a ratio greater than the normal of 1 during the summer, but less than 1 during the winter. The only areas of the lagoon with a DAIN:Si approximating to 1 in the summer are the far east at both low water and high water, whilst the area closest to Faro has a ratio of less than 1 at high water (Fig. 5AII). The deviations from the normal of both DAIN:P and DAIN:Si ratios are apparent at both low and high water.

\subsection{Vertical profiles of nutrients near the sediment- water interface}

Vertical profiles of ammonium, nitrate and phosphate concentrations in overlying waters and pore waters are presented in Fig. 6 for both immersed and air-exposed conditions. Pore water is enriched in nutrients in comparison to the overlying water. The greatest differences are found for ammonium at all situations over both sampling periods: concentrations of ammonium in pore waters may reach $400 \mu \mathrm{M}$, whilst those in overlying water rarely exceed $3 \mu \mathrm{M}$ (Fig. 6Ai,ii). Ammonium concentrations in submerged and air-exposed sediments are comparable, except in February (Fig. 6Ai), where the concentration are higher for cores taken from exposed sediments. Nitrate concentrations in pore waters are two orders of magnitude lower than ammonium levels and the concentration gradients across the sediment-water interface are less pronounced (Fig. 6Bi,ii). However, the situation is different for phosphate where pore water of exposed sediments contains higher concentrations of phosphate compared to those in submerged sediments, both in February and in June (Fig. 6Ci,ii).

\subsection{Estimation of chlorophyll a in the Ria Formosa}

Fig. 7 shows that most of the concentrations of chlorophyll $a$ are low throughout the year, ranging between 2.0 and $3.0 \mu \mathrm{g} \mathrm{dm}^{-3}$. Only one of 220 data points is over $5.0 \mu \mathrm{g} \mathrm{dm}^{-3}$.

\subsection{Estimation of oxygen saturation in the Ria Formosa}

Fig. 8 shows a cumulative frequency curve for 5 years of data on the saturation of 


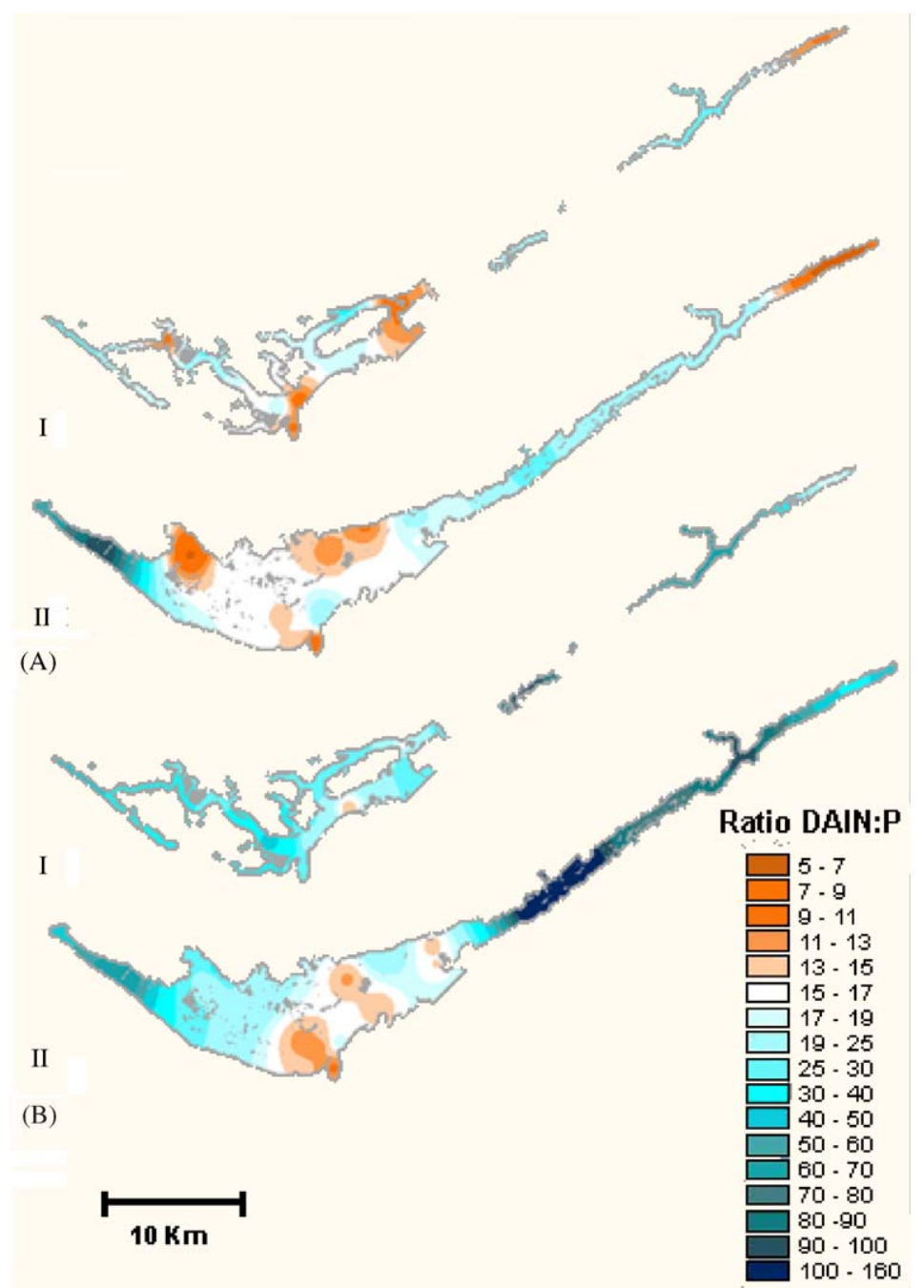

Fig. 4. GIS maps of the ratio of DAIN:phosphate throughout the lagoon based on the stations shown in Fig. 1. (A) Summer conditions: (I) low, (II) high water; (B) winter conditions: (I) low, (II) high water. White and light coloured pigments show ratios that are close to "balanced" conditions (see Fig. 3A).

oxygen. $90 \%$ of these data have saturation values $>90 \%$.

\section{Discussion}

\subsection{Ria Formosa in terms of the European Union Water Framework Directive}

The Ria Formosa could be considered a coastal water under the terms of the EU-WFD
(EEB, 2001), as the salinity regime is not substantially influenced by freshwater for most of the year (Newton and Mudge, in press). The type-specific references for the biological parameters must be established in accordance with the EU-WFD for the Ria Formosa. Some of the physical reference conditions have already been described: hydro-morphological elements supporting the biological elements; morphological conditions; depth variation; quantity, structure and substrate of the bed; structure 


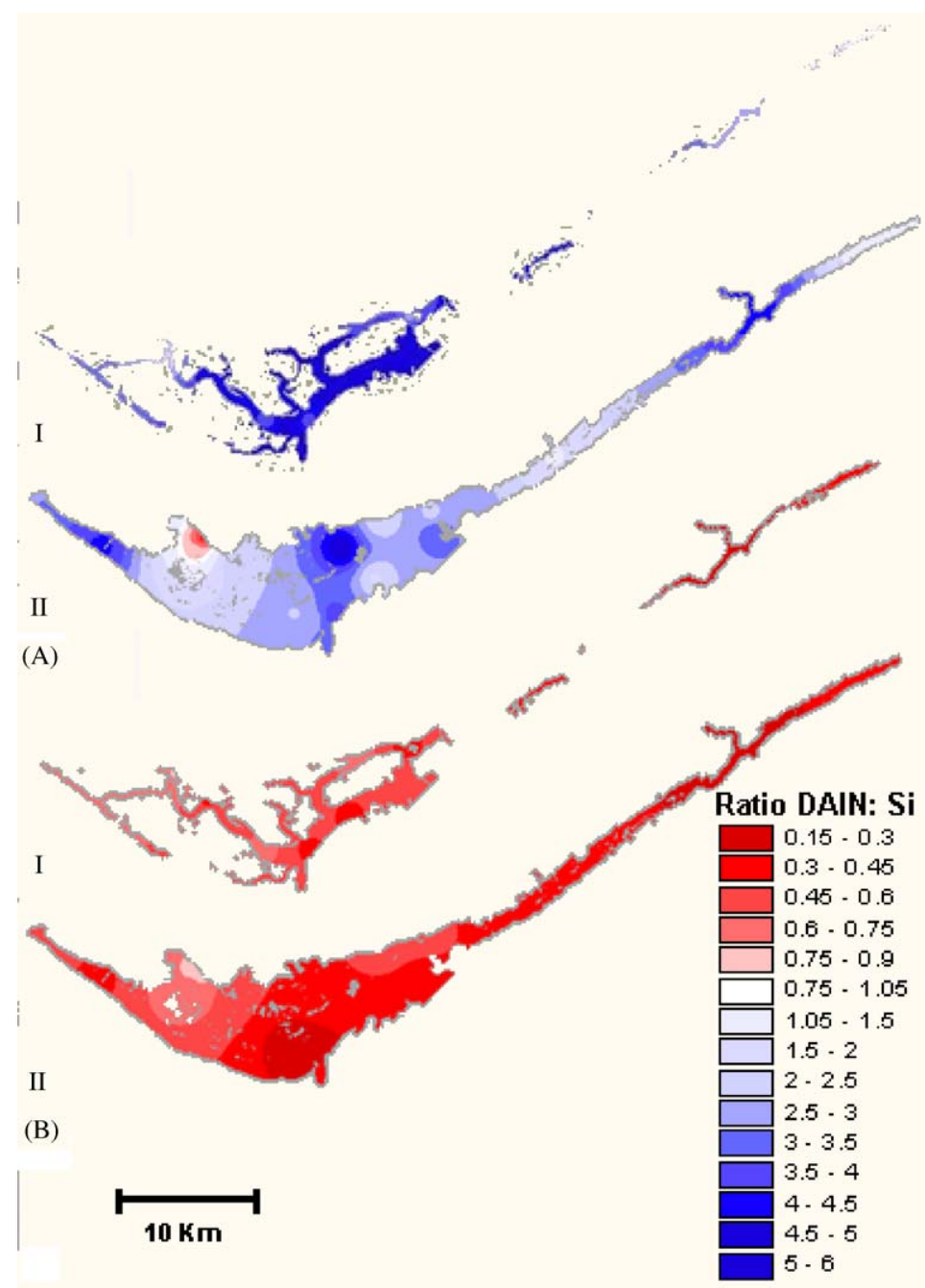

Fig. 5. GIS maps of the ratio of DAIN: silicate throughout the lagoon based on the stations shown in Fig. 1. (A) Under summer conditions at (I) low and (II) high water; (B) under winter conditions at (I) low and (II) high water. White and light coloured pigments show ratios that are close to "balanced" conditions (see Fig. 3B).

of the intertidal zone; tidal regime; freshwater flow; salinity and temperature (Newton and Mudge, in press). These may be used in models to reconstruct biological reference conditions. However, the exact mode of how these parameters will be combined in the WFD has yet to be defined.

Coastal engineering and infrastructure in the western part of the Ria Formosa includes: the main inlet at Barra do Farol; the artificial inlet opening (INDIA project, see arrow in Fig. 1); the construction of an international airport on the mudflats; two large sewage treatment plants to the east and west of Faro town; as well as a system of dykes that effectively dams the Ribeira de São Lourenço. Despite these alterations, the flushing regime and the absence of industry signify that the Ria Formosa can be classified as showing no or only very minor human impact (Newton and Icely, 2002). Lagoons, such as 

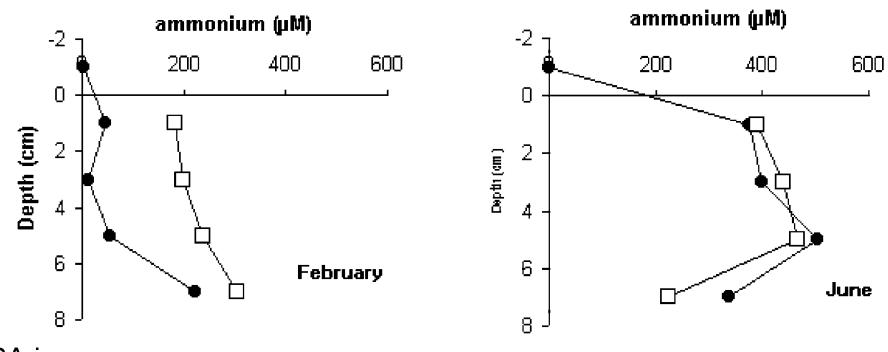

$6 \mathrm{~A} \mathrm{i}$

ii
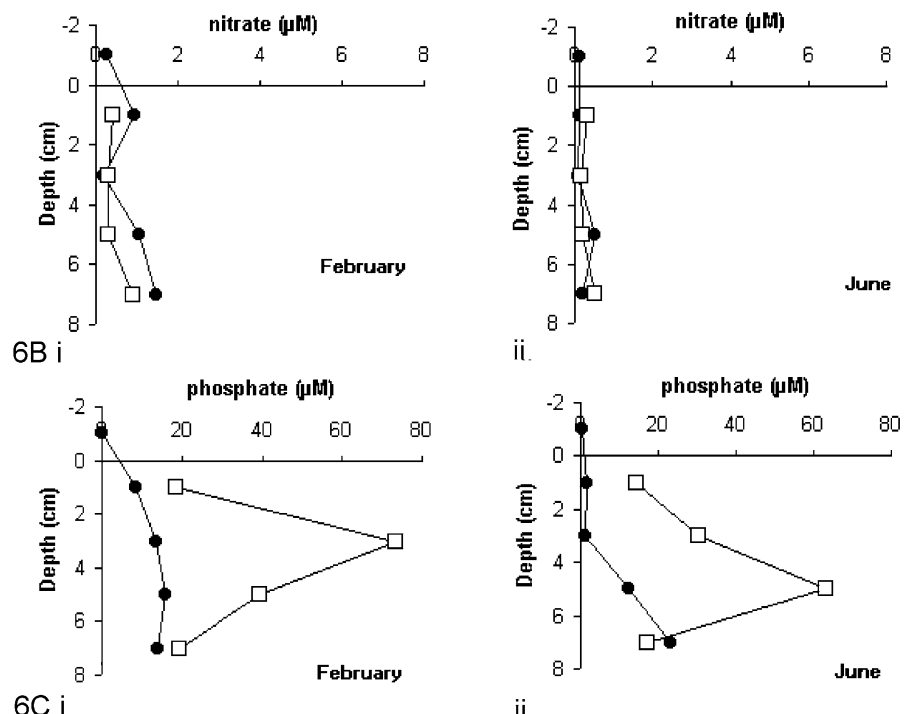

Fig. 6. Nutrient concentrations in sediment cores collected under both exposed ( $\square$ ) and submerged conditions (•). (A) Ammonium: (i) winter, (ii) summer; (B) nitrate: (i) winter, (ii) summer; (C) phosphate: (i) winter, (ii) summer.

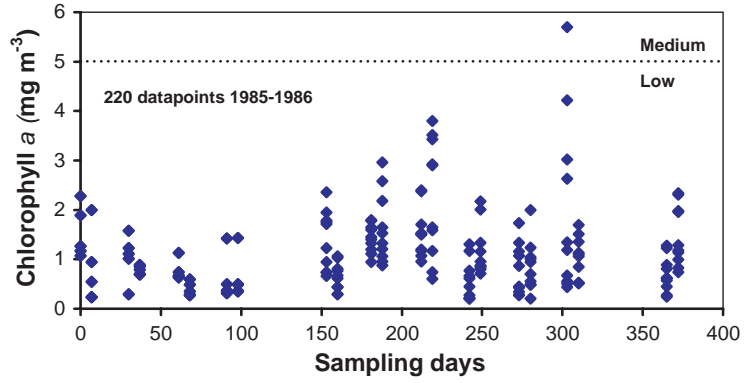

Fig. 7. Chlorophyll $a$ in the lagoon over an annual cycle starting in September 1985. The low-medium division of the NEEA category, for a primary symptom of eutrophication (Bricker et al., 1999), is shown as a dotted line.

Aveiro, Portugal (Abreu et al., 2000) and Venice, Italy (UNESCO, 2000) are far more compromised systems.

\subsection{Nutrient conditions in the water column of the Ria Formosa}

The present paper discusses the chemical and physico-chemical elements supporting the biological elements and in particular the nutrient conditions The concentration of dissolved available inorganic nitrogen, phosphate and silicate (Fig. 2) is much higher in the eastern lagoon where the population density is lower than in the western lagoon, but the proportion of agricultural land is greater. This may indicate that agriculture makes a greater contribution to nutrient inputs than sewage. Indeed, the particularly high concentrations of nutrients in the eastern lagoon during winter months can be attributed, in part to freshwater run off. There is evidence for an increase of both 


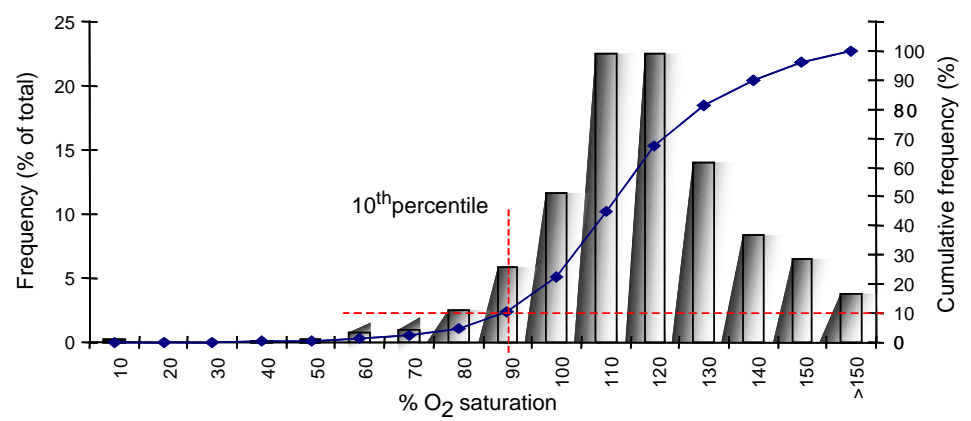

Fig. 8. Frequency distribution and cumulative frequency of percentage oxygen saturation measured in the lagoon over a 5 year period.

DAIN and phosphate in the early summer which might be related to increases in population from tourism (Fig. 2A and B) Fluctuating winter and summer populations can significantly skew nutrient loadings in tourist areas (Aguilera et al., 2001). However, the greatest fluctuations are in the eastern lagoon where tourism is relatively low. Indeed, blooms of diatom assemblages, both planktonic and microphytobenthos, have an important influence on nutrient concentrations in lagoon systems and may explain many of the fluctuations in nutrient concentrations. For example, there is marked decline in both DAIN and phosphate in both the early spring and the early autumn.

This analysis of changes in the mean values of nutrients in the water column has demonstrated differences between the eastern and western lagoon, particularly, in relation to DAIN and silicate. The importance of DAIN in eutrophic processes is well known (see reference in Cardoso et al., 2001), but Conley et al. (1997) have also emphasised the importance of silicon in these processes. However, this broad analysis does not show the role of the sediments in moderating nutrient concentrations in the water column, nor does it show up 'hot spots' such as urban centres or sewage outfalls that might contribute to potential eutrophic conditions in the lagoon.

\subsection{Nutrient conditions at the sediment-water interface of the Ria Formosa}

Sediments are particularly important in a shallow system like the Ria Formosa where there is a high surface area to volume ratio (Conley et al., 1997). Sediments have been shown to be reservoirs or sinks for nutrients (del Amo et al., 1997; Prastka et al., 1998; Sundareswar et al., 2001). However, they can also act as a source depending on the redox conditions in the sediments (House and Denison, 2000).

Analysis of nutrient concentrations in the sediment cores from the Ria Formosa during the winter and summer (Fig. 6) provide values to predict fluxes of ammonium, nitrate and phosphate across the sediment-water interface using Fick's first law of diffusion (Berner, 1980). Table 1 summarises these values for both sandy and muddy sediments under summer and winter conditions.

The largest fluxes are of the order of $1000 \mathrm{nmol} \mathrm{cm}^{-2} \mathrm{~d}^{-1}\left(0.001 \mathrm{M}\right.$ per $\mathrm{m}^{2}$ per day) for ammonium from muddy sediments during the summer. Although the contribution of nitrate to total nitrogen is minimal, the DAIN:P ratio is in the thousands, which is much higher than the Redfield ratio of 16 . This high production of ammonium is attributed to the intense decomposition of organic matter. The fluxes of nutrients are also affected by tidal conditions, with currents during tidal inundation flushing the surface layer of the sediment. Differences between the sub-tidal and inter-tidal conditions indicate the existence of complex processes associated with inundation and exposure of sediments (Falcão and Vale, 1995, 1998; Rocha, 2000). Essentially, nutrients that influence the metabolic activity of the sediment community may be removed (Kerner and Wallmann, 1992). For example, phosphate is more 
Table 1

Typical fluxes measured in the Ria Formosa for the diffusion of ammonium, nitrate and phosphate $\left(\mu \mathrm{mol} \mathrm{cm}^{-2} \mathrm{~d}^{-1}\right)$ from sandy and muddy sediments in June and February

\begin{tabular}{|c|c|c|c|c|c|c|}
\hline & \multicolumn{2}{|c|}{$\mathrm{NH}_{4}\left(\mu \mathrm{mol} \mathrm{cm}{ }^{-2} \mathrm{~d}^{-1}\right)$} & \multicolumn{2}{|c|}{$\mathrm{NO}_{2}\left(\mu\right.$ molc cm $\left.{ }^{-2} \mathrm{~d}^{-1}\right)$} & \multicolumn{2}{|c|}{$\mathrm{PO}_{4}\left(\mu \mathrm{mol} \mathrm{cm}{ }^{-2} \mathrm{~d}^{-1}\right)$} \\
\hline & Sand & Mud & Sand & Mud & Sand & Mud \\
\hline June $\left(26^{\circ} \mathrm{C}\right)$ & 3.3 & 150 & 1.5 & 3.5 & 2.5 & 7.2 \\
\hline February $\left(10^{\circ} \mathrm{C}\right)$ & 1.5 & 55 & 0.5 & 0.6 & 0.2 & 1.2 \\
\hline
\end{tabular}

readily transferred to the water column under the reduced conditions of an immersed sediment compared to the oxic conditions of a sediment that has been flushed by tidal currents (Slomp et al., 1998). This is also illustrated in Fig. 6c where the concentration of phosphate is much higher in the cores from the immersed sediments in both summer and winter.

On the basis of this and a previous study (Falcão and Vale, 1998), it is estimated that $7-150 \mu \mathrm{mol} \mathrm{cm} \mathrm{cm}^{-2} \mathrm{~d}^{-1}$ of ammonium and 1.5$30 \mu \mathrm{mol} \mathrm{cm}{ }^{-2} \mathrm{~d}^{-1}$ of phosphate are transferred from the sediments to the water column when the intertidal sediments are flooded by the incoming tide, providing an important source of nutrients for the primary producers in the lagoon and an important factor to take into consideration for any evaluation of eutrophication in the Ria Formosa.

\subsection{Evaluation of eutrophication in the Ria Formosa based on EU European Environmental Agency Criteria (EEA, 1999a)}

The EU-WFD (EEB, 2001), in contrast to the USA survey (Bricker et al., 1999), places emphasis on the measurement of nutrient concentrations in water quality assessments. The EEA (2001) states that the present state of eutrophication is to be assessed in terms of winter nutrient concentrations, chlorophyll- $a$ and bottom oxygen concentrations. Nutrient concentrations give the best spatial resolution in the assessment of eutrophication (EEA, 2001).

However, an evaluation of eutrophication in the Ria Formosa must necessarily take into account the criteria which should be used to define it. The EEA (1999a) for instance, establishes a lower limit of $16 \mu \mathrm{mol} \mathrm{NO} \mathrm{NO}_{3}^{-} \mathrm{dm}^{-3}$ as the threshold for bad quality. The EEA eutrophication report (2001) reports baseline data for the English Channel of 16.77 and $10.63 \mu \mathrm{mol} \mathrm{NO}-\mathrm{dm}^{-3}$ for the Irish Sea. Offshore time-series in the Portuguese Atlantic coast indicate mean values of $11 \mu \mathrm{mol} \mathrm{NO}-\mathrm{dm}^{-3}$.

The quality status of DAIN on the basis of the EEA criteria was "bad", in the eastern lagoon, particularly during the winter months, with concentrations that were greater than $16 \mu \mathrm{mol} \mathrm{dm}^{-3}$ (Fig. 2A). This could be attributed to rainfall (Fig. 2A) over this period. In the western lagoon, the concentration of DAIN varied from "poor" to "bad" during most of the year. However, the concentrations were "fair" to "good" throughout the lagoon during the early summer, with concentrations of less than $9.0 \mu \mathrm{mol} \mathrm{dm}{ }^{-3}$.

Again, the quality status of phosphorous was "bad" in the eastern lagoon during the winter months, with concentrations $>1.7 \mu \mathrm{mol} \mathrm{dm}{ }^{-3}$ that could be linked to rainfall (Fig. 2B). For most of the year, the status was "poor" with concentrations of $0.7-1.1 \mu \mathrm{mol} \mathrm{dm}{ }^{-3}$ throughout the lagoon. However, the status was "fair" to "good" in the western lagoon during the summer and early autumn.

The Redfield ratio (DAIN:P) continues to be an important tool in understanding the marine biogeochemical cycles (Lenten and Watson, 2000). Indeed, the EEA (1999a, b) emphasises the use of nutrient ratios, especially DAIN:P, for the assessment of eutrophication. The DAIN:P ratio (Fig. 3A) is close to normal (16) from early spring through to early summer suggesting that phosphorous may be limiting. This is an unusual situation in a shallow marine system where there is a large area of contact with the sediments. However, phosphorous limitation in coastal 
lagoons has been reported, (Attayde and Bozelli, 1998). The interpretation and modelling of nutrient data is particularly difficult in very shallow systems (Nixon et al., 2001). An alternative interpretation is that there is a large excess of nitrogen in the system, particularly in the eastern lagoon, an area where there is a lot of intensive agriculture. UNESCO (1999) assesses the extent of non-point source pollution to aquatic ecosystems. Run off from agriculture may contribute large quantities of nutrients to the Ria Formosa during the winter months. Seasonal rainfall is sporadic in the region so excess fertiliser that accumulates over several months can be suddenly flushed into the eastern lagoon. It is also important to remember the contributions to the nutrients from the sediments demonstrated by the survey in this current study.

Nevertheless, the present study probably has underestimated the amount of biologically available nitrogen in the Ria Formosa. The contribution of dissolved organic nitrogen (DON) has not been taken into consideration in this study, although DON can account for a significant percentage of biologically available nitrogen (Seitzinger and Sanders, 1997), nor have atmospheric inputs been quantified (Paerl et al., 2002). The decrease in the DAIN:P ratio in the spring is probably due to algal blooms.

The ratio of DAIN:Si is, also, an important tool for understanding nutrient inputs (Rahm et al., 1996). The summer peak in the DAIN:Si ratio (Fig. 3B) is less pronounced in the eastern lagoon because of the freshwater input from the Gilão. This river still flows in the summer whereas many of the other streams dry up completely. Dykes effectively dam the Ribeira de São Lourenço and this may well affect the supply of dissolved silicon in the western lagoon. The disruptive effect of dams has been discussed by Humborg et al. (2000). The smaller spring peak in the DAIN:Si ratio is probably due to the consumption of silicate during the spring diatom bloom. The importance of the Si:DIN ratio has been emphasised by Turner et al. (1998).

There is still a lot of discussion on how useful nutrient ratios are in eutrophication studies, and which ratios should be used, DAIN:Si or Si:DIN or N:P:Si or Si:N:P. Whether these ratios reflect nutrient limitation at all, when the concentrations are high, is discussed by EEA (1999a). Furthermore, there is evidence that the limiting nutrient may change during the year, $\mathrm{P}$ in spring, $\mathrm{N}$ in summer and $\mathrm{Si}$ at the end of the diatom bloom (Conley, 1999).

The main objective of the general survey of the Ria Formosa was to identify whether there were areas within the lagoon where the characteristics of the water were significantly altered in comparison to the inflowing coastal seawater. Inadequate tidal flushing in such areas may lead to deterioration of water quality, particularly during certain seasons of the year. Furthermore, the tidal export of nutrients from the lagoon may only be exporting the potential for eutrophication, especially when the exported nutrient is normally limited in the adjacent coastal water (Conley, 1999).

An additional management tool for the interpretation of the nutrient status of coastal ecosystems is the formation GIS maps (Kitsou et al., 2002) that, in the case of the Ria Formosa, have been produced by combining the nutrient ratios calculated from the relational data base with GIS (Figs. 4 and 5). Ideally more stations should be used, nevertheless, "hot spots" are clearly visible at both high and low water, including the area around the town of Faro and the eastern lagoon. This suggests that, although tidal flushing of the Ria Formosa is high, it may be inadequate for the level of nutrients accumulating in the inner lagoon. The importance of seasonal changes in modifying nutrient status (Conley, 1999) is especially apparent for DAIN:Si in the Ria Formosa where the status changes completely between summer and winter (Fig. 5).

\subsection{Alternative assessment of eutrophication in the Ria Formosa based on the US National Estuarine Eutrophic Assessment (Bricker et al., 1999)}

The category range and classifications proposed by EEA should be subjected to close scrutiny: under the EEA classification, the Ria Formosa frequently scores as "poor" to "bad"; however, if mean chlorophyll $a$ values for this system are 
examined (Fig. 7), mean values are in the range of about $2-3 \mu \mathrm{g}$ chl $a \mathrm{dm}^{-3}$.

This is in the "low" eutrophication category of the NEEA study (Bricker et al., 1999). Estimated annual phytoplankton primary production based on a carbon:chlorophyll ratio of 35 (Baretta and Ruardij, 1988) and an (excessive) assimilation number of 20 gives a value of $2 \mathrm{gC} \mathrm{m}^{-2} \mathrm{yr}^{-1}$ for a $1 \mathrm{~m}$ mean depth, that is well within the oligotrophic definition given by Nixon (1995).

If the oxygen concentrations in the Ria Formosa are considered, using the NEEA secondary symptom approach (Bricker et al., 1999), it is seen that $90 \%$ of measured values are above $90 \%$ saturation (Fig. 8), that would indicate that the system is near-pristine.

The application of different classification methodologies, therefore, results in a wide range of possible status categories for eutrophication. Great care must be taken in the intercomparison of the various indices which are proposed for assessing and rating coastal ecosystems, to ensure that a fair evaluation can be made. It is important to note that Bricker et al. (1999) specifically excluded nutrients from the list of criteria, because a study of 138 estuaries did not allow a connection to be made between nutrient levels and symptoms of eutrophication.

\subsection{Driving forces, Pressures, State, Impact,} Responses (DPSIR) assessment of eutrophication in the Ria Formosa

Driving forces, Pressures, State, Impact, Responses (DPSIR) assessments can be a useful management tool in assessing eutrophication (EEA, 1999b).

\subsubsection{Driving forces}

Eutrophication of the Ria Formosa may be caused by an excess loading of nitrogen and phosphorous nutrients from human activities. The main source of nitrogen is run-off from agricultural land brought to the lagoon via runoff (non-point source), as well as torrential streams and rivers such as the Gilão (point source). Atmospheric deposition of nitrogen may also contribute significantly to the total nitrogen load, but this additional non-point source has not been studied. Atmospheric nitrogen originates partly from ammonia evaporation from animal husbandry and partly from combustion of fossil fuels in traffic, industry and households. There are large pig and chicken farms in the Ria Formosa watershed. Most of the anthropogenic phosphorous comes from households and industry discharging treated or untreated wastewater to freshwater or directly to the Ria Formosa. The effectiveness of the large water treatment plants in the Ria Formosa is being tested. Soil erosion and the sediment interface are other important sources of phosphorous. The presence of a large buffer of phosphorus in coastal sediments is the main reason why the reduction in phosphate inputs is not reflected immediately by a reduction in phosphate concentrations (EEA, 2001).

Aquaculture in the Ria Formosa is mainly of bivalve filter-feeders although fish and prawn farms may also cause eutrophication problems. Prior to the installation of sewage treatment plants (ETAR) the discharge of raw or poorly treated wastewater was a major problem in the lagoon (Mudge and Bebianno, 1997). All these different variables must be taken into consideration to achieve good integrated coastal zone management (ICZM) and hence multidisciplinary studies are essential (Fabbri, 1998).

\subsubsection{Pressures}

The main increase in nutrient load in the Algarve has taken place since the 1970s and monitoring started soon after, in the early 1980s. There was a decline in traditional agriculture during this period and an increase in intensive farming, in greenhouses as well as intensive chicken and pig farms. Simultaneously there was a large increase in urbanization of the area surrounding the lagoon. Sewage treatment plants were put in operation in the late 1990s.

\subsubsection{State}

Eutrophication is assessed in terms of winter nutrient concentrations, chlorophyll- $a$ and bottom oxygen concentrations (EEA, 2001). The winter nutrient concentrations of the Ria Formosa were in the "poor" to "bad" quality status, especially in 
the eastern lagoon. These high concentrations were related to periods of rainfall in an agricultural watershed.

Maps of nutrient ratios gave the assessment of areas where eutrophication may be a problem, although spatial resolution needs to be improved. Analysis of the relationship between nutrients and river flow showed a consistent pattern of eutrophic conditions in areas receiving a greater freshwater input from urban and, especially, agricultural catchments.

Low oxygen concentrations used in the definition of hypoxia $\left(<2 \mathrm{mg} \mathrm{dm}^{-1}\right)$ is not a good choice in the Ria Formosa, where water temperatures can reach $27^{\circ} \mathrm{C}$. Saturation is a better measure of oxygen availability in these circumstances. Events of oxygen depletion have been recorded (Ria Formosa and Huelva) as the combined result of high organic load, weak local circulation, high primary productivity and temperature (OSPAR, 2000). Newton (1995) reported a morning oxygen sag (48\% saturation) and afternoon supersaturation, especially during the summer months. No anoxic bottom water layer was found in the survey of the Ria Formosa, and only ephemeral stratification at the seawater inlets and near the mouth of the river Gilão (Newton and Mudge, in press). Stratification was an important factor in the formation of an anoxic layer in a Mediterranean lagoon (Souchu et al., 1998).

\subsubsection{Impacts}

The declining bivalve harvest (Dinis, 1992) is one of the most serious economic consequences of the degradation of water quality in the Ria Formosa. Clam farmers also report an increase in the mortality of their stock, with mass mortalities in some areas of the lagoon (Lourenço, pers. comm.). There is some evidence that the incidence of harmful algal blooms are increasing (Baptista, 1993). Fish kills also occur with increasing frequency in the summer months. No persistent anoxic bottom layer has been reported, although large areas of the lagoon have anoxic sediments just below the interface. Padinha et al. (2000) have documented the decrease in seagrasses and there is a large increase in algal mats and Ulva.
Many of the symptoms reported above are primary or secondary symptoms of eutrophication (Bricker et al., 1999).

\subsubsection{Responses}

1. An appropriate monitoring network for the ecological, chemical status and the volume and level or rate of flow (as relevant to the ecological and chemical status) should be established for the Ria Formosa by the national and regional authorities.

2. Nitrogen and phosphorus nutrients, chlorophyll- $a$ and oxygen concentrations are the eutrophication variables recommended by the EEA and should be monitored.

3. Other primary and secondary symptoms of eutrophication should also be monitored (Bricker et al., 1999). Primary symptoms include algal abundance (using chlorophyll $a$ as an indicator), epiphyte abundance, and macroalgae. Secondary symptoms include submerged aquatic vegetation loss, nuisance and toxic algal blooms, and low dissolved oxygen (anoxia and hypoxia). Oxygen percentage should be monitored as well as concentration.

4. Monitoring should include measurements of phytoplankton species composition, macrophyte biomass, species composition and depth distribution, and macrozoobenthos biomass and species composition.

5. Regular monitoring is essential as time series of 5 years or more are needed for trend analysis.

6. Eutrophication data, including reporting under the EU directives, should be reported to the databases of the marine conventions and/ or to EEA.

7. Routines to assure the quality and completeness of contributed data should be developed.

8. Atmospheric deposition of $\mathrm{N}$ should be assessed in the Ria Formosa watershed.

9. The contribution of the sediments to the supply of nutrients and organic matter require further study.

10. Nutrients and organic matter load from aquaculture should be included in future pollution load compilations. 
11. Remote sensing, aerial photography and GIS should be combined with the data bases for the geochemical and ecological modeling of the eutrophication data bases.

12. The use of TRIX, EUTRIX, PSA and equation indices should be tested in the Ria Formosa, as well as the index used in the USA (Bricker et al., 1999).

13. The effect of seasonal population changes should be evaluated.

14. The impact of rainfall pattern and climate change trends (Justic et al., 1996) should be evaluated.

\section{Conclusions}

It is evident that using different models for assessing eutrophication produces very different conclusions. If the Ria Formosa is assessed on the EEA criteria based on the comparison of nutrient levels in transitional and coastal waters, the situation in the Ria Formosa is "poor" to "bad" (see Figs. 3-5). On the other hand, if the Ria Formosa is assessed by the NEEA criteria based on symptoms of eutrophication, such as high Chlorophyll $a$ or low oxygen saturation, the situation in the Ria Formosa is near pristine (see Figs. 7 and 8). These differences of opinion can only be reconciled by a critical analysis of the criteria used by the various eutrophication models and by detailed comparison of the different models using the same data sets. The objectives of the current EU funded OAERRE project are targeted towards this work, which should allow for a better understanding of the current eutrophication status of the Ria Formosa.

\section{Acknowledgements}

Part of this work was funded by EU contract EVK3-CT1999-00002. We thank Drs Cristina Cardoso and Stephen Mudge for their critical appraisal of the manuscript.

\section{References}

Abreu, S.E., Pereira, C., Vale, C., Duarte, A.C., 2000. Accumulation of mercury in sea bass from a continental lagoon (Ria de Aveiro, Portugal). Marine Pollution Bulletin 40, 293-297.

Aguilera, P.A., Castro, H., Rescia, A., Schmitz, M.F., 2001. Methodological development of an index of coastal water quality: application in a tourist area. Environmental Management 27, 295-301.

Andrade, C., 1990. O Ambiente de Barreira da Ria Formosa, Algarve, Portugal, Dissertação de Doutoramento em Geologia do Ambiente, Departamento de Geologia da Universidade de Lisboa. Unpublished thesis.

Attayde, J.L., Bozelli, R.L., 1998. Environmental heterogeneity patterns and predictive models of chlorophyll $a$ in a Brazilian coastal lagoon. Hydrobiologia 390, 129-139.

Baptista, T.M.C., 1993. Microbiological observations in the Ria Formosa. M.Phil. Thesis, University of Wales, UK, unpublished.

Baretta, J., Ruardij, P. (Eds.), 1988. Tidal flat estuaries. In: Simulation and Analysis of the Ems Estuary. Springer, Berlin, 353pp.

Bebianno, M.J., 1995. Effects of pollutants in the Ria Formosa lagoon. Science of the Total Environment 171, 107-115.

Berner, R., 1980. Early Diagenisis. A Theoretical Approach. Princeton University Press/Prentice-Hall, Princeton/Englewood Cliffs, USA, p. 397.

Bricker, S.B., Clement, C.G., Pirhalla, D.E., Orlando, S.P., Farrow, D.R.G., 1999. National estuarine eutrophication assessment: Effects of nutrient enrichment in the nation's estuaries. NOAA, National Ocean Service, Special Projects Office and the National Centers for Coastal Ocean Science, Silver Spring, MD, p. 71.

Cardoso, A.C., Duchemin, J., Magoarou, G., Premazzi, G., 2001. Criteria for the identification of freshwaters subject to eutrophication. Their use for the implementation of the "Nitrates" and "Urban Waste Water Treatment Directive". Office for official publications of the European Communities, Luxembourg, p. 87.

Caumette, P., Castel, J., Herbert, R. (Eds.), 1996. Coastal Lagoon Eutrophication and Anaerobic Processes. Nitrogen and sulfur cycles and population dynamics in coastal lagoons Developments in Hydrobiology, Vol. 117. Kluwer Academic Publishers Dordrecht, p. 256.

Cloern, J.E., 2001. Our evolving conceptual model of the coastal eutrophication problem. Marine Ecology Progress Series 201, 223-253.

Conley, D.J., 1999. Biogeochemical nutrient cycles and nutrient management strategies. Hydrobiologia 410, 87-96.

Conley, D.J., Stockenberg, A., Carman, R., Johnstone, R.W., Rahm, L., Wulff, F., 1997. Sediment-water nutrient fluxes in the Gulf of Finland, Baltic. Estuarine, Coastal and Shelf Science 45, 591-598.

del Amo, Y., Queguiner, B., Treguer, P., Breton, H., Lampert, L., 1997. Impacts of high-nitrate freshwater inputs on macrotidal ecosystems. II. Specific role of the silicic acid pump in the year-round dominance of diatoms in the Bay of Brest (France). Marine Ecological Progress Series 161, 225-237. 
Dinis, M.T., 1992. Situação da aquacultura no Algarve: perspectivas e condicionantes. In: Mesas redondas, Ponte International do Guadiana, Fev. 1992.

Dionisio, L.P., Rheinheimer, G., Borrego, J.J., 2000. Microbiological pollution of Ria Formosa (South of Portugal). Marine Pollution Bulletin 40, 186-193.

Druon, J.-N., Schrimpf, W., Dobricic, S., Stips, A., 2002. The physical environment as a key factor in assessing the eutrophication status and vulnerability of shallow seas: PSA \& EUTRISK (v1.0). Office for official publications of the European Communities, p. 40.

EEA, European Environment Agency, 1999a. Nutrients in European Ecosystems. Environmental Assessment Report No. 4. Office for official publications of the European Communities, p. 155.

EEA, European Environment Agency, 1999b. Environmental signals 2000. Environmental Assessment Report No. 6. Office for official publications of the European Communities, p. 108.

EEA, European Environment Agency, 2001. Eutrophication in Europe's coastal waters. Topic report No. 7, Copenhagen, p. 86.

EEB, 2001. European Environmental Bureau. Handbook on EU Water Policy under the Water Framework Directive, Brussels, p. 56.

Fabbri, K.P., 1998. A methodology for supporting decision making in integrated coastal zone management. Ocean \& Coastal Management 39, 51-62.

Falcão, M., 1997. Dinâmica dos nutrientes na Ria Formosa: interacção da laguna com as suas interfaces na reciclagem do azoto, fósforo e sílica. Ph.D. Thesis, University of the Algarve, Portugal, Unpublished.

Falcão, M., Vale, C., 1995. Tidal flushing of ammonium from inter-tidal sediments of Ria Formosa, Portugal. Netherlands Journal of Aquatic Ecology 29, 239-244.

Falcão, M., Vale, C., 1998. Sediment-water exchanges of ammonium and phosphate in intertidal and subtidal areas of a mesotidal coastal lagoon (Ria Formosa). Hydrobiologia 373, 193-201.

Ferreira, J.G., 2000. Development of an estuarine quality index based on key physical and biogeochemical features. Ocean and Coastal Management 43, 99-122.

Grasshoff, K., 1976. Methods of Seawater Analysis. Verlag Chemie, New York, p. 317.

Grasshoff, K., Erkhardt, M., Kremling, K., 1983. Methods of Seawater Analysis. Verlag Chemie, New York, p. 419.

House, W.A., Denison, F.H., 2000. Factors influencing the measurement of equilibrium phosphate concentrations in river sediments. Water Research 34, 1187-1200.

Humborg, C., Conley, D.J., Rahm, L., Wulff, F., Cociasu, A., Ittekot, V., 2000. Silicon retention in river basins: far reaching effects on biogeochemistry and aquatic food webs in coastal marine environments. Ambio 29, 45-59.

INAG (Instituto da Agua), 2002. Serviço Nacional de Informação de Recursos Hídricos. http://snirh.inag.pt.

Isaaks, E.H., Srivastava, R.M., 1989. An Introduction to Applied Geostatistics. Oxford University Press, New York, p. 259.
Jackson, J.B.C., 2001. What was natural in the coastal oceans? Proceedings of the National Academy of Sciences USA 98, 5411-5418.

Justic, D., Rabalais, N.N., Turner, R.E., 1996. Effects of climate change on hypoxia in coastal waters: a doubled $\mathrm{CO}_{2}$ scenario for the Northern Gulf of Mexico. Limnology and Oceanography 41, 992-1003.

Kerner, M., Wallmann, K., 1992. Remobilization events involving $\mathrm{Cd}$ and $\mathrm{Zn}$ from intertidal flats sediments in the Elbe Estuary during the tidal cycle. Estuarine, Coastal and Shelf Science 35, 371-393.

Kitsou, D., Coccossis, H., Karydis, M., 2002. Multi-dimensional evaluation and ranking of coastal areas using GIS and multiple criteria choice methods. Science of the Total Environment 284, 1-17.

Lenten, T.M., Watson, A.J., 2000. Redfield revisited I, regulation of nitrate, phosphate and oxygen in the ocean. Global Biogeochemical Cycles 14, 225-268.

Mudge, S.M., Bebianno, M.J., 1997. Sewage contamination following an accidental spillage in the Ria Formosa, Portugal. Marine Pollution Bulletin 34, 163-170.

Mudge, S.M., Bebianno, M.J., 1998. Trace organic matter in the Ria Formosa, Portugal. Chemistry and Ecology 14, 265-277.

Mudge, S.M., East, J.A., Bebianno, M.J., Barreira, L., 1998. Trace organic compounds in the Ria Formosa Lagoon, Portugal: fatty acids. Organic Geochemistry 29, 963-977.

Mudge, S.M, Bebianno, M.J., East, J.A., Barreira, L., 1999. Sterols in the Ria Formosa Lagoon, Portugal. Water Research 33, 1038-1048.

Newton, A., 1995. The water quality of the Ria Formosa, Portugal. Ph.D. Thesis, University Wales, Bangor, UK, unpublished.

Newton, A., Icely, J.D., 2002. Impact of coastal engineering on the water quality of the Ria Formosa Lagoon, Portugal. EURCOAST/EUCC Porto, Portugal. The Changing Coast Littoral 3, 417-421.

Newton, A., Mudge, S.M., Shallow, mesotidal lagoons: temperature and salinity regimes in the Ria Formosa, Portugal. Estuarine, Coastal and Shelf Science, in press.

Newton, A., Mudge, S.M., Nutrient budgets in the Ria Formosa, Portugal. Estuarine, Coastal and Shelf Science, submitted.

Nixon, S.W., 1995. Coastal marine eutrophication: a definition, social causes and future concerns. Ophelia 41, 199-219.

Nixon, S.W., Buckley, B., Granger, S., Bintz, J., 2001. Responses of very shallow marine ecosystems to nutrient enrichment. Journal of Human and Ecological Risk Assessment 7, 1457-1481.

NRC, 2000. Clean coastal waters: understanding and reducing the effects of nutrient pollution. National Research Council, Committee on the Causes and Management of Eutrophication, Ocean Studies Board, Water Science and Technology Board, p. 428.

OSPAR, 2000. Quality Status Report 2000, Region IV-Bay of Biscay and Iberian coast. OSPAR Commission, London, p. 134. 
Padinha, C., Santos, R., Brown, M., 2000. Evaluating environmental contamination in Ria Formosa (Portugal) using stress indexes of Spartina maritima. Marine Environmental Research 49, 67-78.

Paerl, H.W., Dennis, R.L., Whitall, D.R., 2002. Atmospheric deposition of nitrogen: implications for nutrient overenrichment of coastal waters. Estuaries 25, 677-693.

Prastka, K., Sanders, R., Jickells, T., 1998. Has the role of estuaries as sources or sinks of dissolved inorganic phosphorous changed over time? Results of a K-d study. Marine Pollution Bulletin 36, 718-728.

Rahm, L., Conley, D., Sandén, P., Wulff, F., Sålnacke, P., 1996. Time series analysis of nutrient inputs to the Baltic Sea and changing DSi: DIN ratios. Marine Ecology Progress Series 130, 221-228.

Rocha, C., 2000. Density-driven convection during flooding of warm, permeable intertidal sediments: the ecological importance of the convective turnover pump. Journal of Sea Research 43, 1-14.

Seitzinger, S.P., Sanders, R.W., 1997. Contribution of dissolved organic nitrogen from rivers to estuarine eutrophication. Marine Ecology Progress Series 159, 1-12.

Simas, M.T., Nunes, J.P., Ferreira, J.G., 2001. Effects of global climate change on coastal salt marshes. Ecological Modelling 139, 1-15.

Slomp, C.P., Malschaert, J.F.P., Van Raaphorst, W., 1998. The role of adsorption in sediment-water exchange of phosphate in North Sea continental margin sediments. Limnology and Oceanography 43, 835-846.

Souchu, P., Gase, A., Collos, Y., Vaquer, A., Tournier, H., Bibent, B., Deslous-Paoli, J.M., 1998. Biogeochemical aspects of bottom anoxia in a Mediterranean Lagoon (Thau, France). Marine Ecology Progress Series 164, 135-146.
Sundareswar, P.V., Morris, J.T., Pellechia, P.J., Cohen, H.J., Porter, D.E., Jones, B.C., 2001. Occurrence and ecological implications of pyrophosphate in estuaries. Limnology and Oceanography 46, 1570-1577.

Taylor, D.I., Nixon, S.W., Granger, S.L., Buckley, B.A., 1999. Responses of coastal lagoon plant communities to levels of nutrient enrichment: a mesocosm study. Estuaries 22, 1041-1056.

Turner, R.E., Rabalais, N.N., 1994. Coastal eutrophication near the Mississippi River delta. Nature 368, 619-621.

Turner, R.E., Qureshi, N., Rabalais, N.N., Dortch, Q., Justic, D., Shaw, R.F., Cope, J., 1998. Fluctuating silicate: nitrate ratios and coastal plankton food. Proceedings of the National Academy of Sciences USA 95, 13048-13051.

UNESCO, 1999. Assessment of and control of nonpoint source pollution of aquatic ecosystems - A practical approach. In: Thornton, J.A., Rast, W., Holland, M.M., Jolankai, G., Ryding, S.O. (Eds.), Man and the Biosphere Series, Vol. 23, UNESCO, Paris, p. 466.

UNESCO, 2000. The Venice Lagoon ecosystem: inputs and interactions between land and sea. In: Lasserre, P., Marzollol, A. (Eds.), Man and the Biosphere Series, Vol. 25, UNESCO, Paris, p. 508.

Vollenweider, R.E., 1976. Advances in defining critical loading levels for phosphorous in lake eutrophication. Memoire dell'Istituto Italiano Idriobiologia 33, 53-83.

Vollenweider, R.A., Giovanardi, F., Montanari, G., Rinaldi, A., 1998. Characterisation of the trophic conditions of marine coastal waters with special reference to the NW Adriatic Sea: proposal for a trophic scale, turbidity and generalised water quality index. Environmetrics 9, 329-357.

Yentsch, C.S., Menzel, D.W., 1963. A method for determination of phytoplankton chlorophyll and phaeophytin by fluorescence. Deep Sea Research 10, 221-251. 